\title{
The Effect Of Acyclovir On The Kidney Of Albino Rats; Histological And Immunohistochemical Study
}

\author{
Amir M. Bassam*, El-Sayed G. Khedr*, Salah E. Mourad** And \\ Gamal.M. Abou L Hassan** \\ Departments of Histology* and Anatomy** Al Azhar University
}

\begin{abstract}
Absrract
Introduction: Acyclovir was the first agent in a novel group of antiviral medications called nucleosides analogues. Acyclovir is commonly used in the treatment of many types of viral infections with minimal side effect.

Aim of the work: The aim of this study was to evaluate the histological and immunohistochemical effect of Acyclovir, antiviral drug, on the kidney of albino rats.

Material and methods: Forty male albino rats have been used and divided into four groups, ten rats each. The first was served as a control group; the second group was treated for one week with $432 \mathrm{mg} / \mathrm{Kg} \mathrm{B}$.Wt acyclovir; the third group was treated for 2 weeks; and finally the forth group was served as recovery group, where animals were examined two weeks after stopping-the drug. Rats were decapitated and kidney specimens were taken and stained with Haematoxylin and Eosin as well as immunostaining using Bcl2 monoclonal antibody.

Result: Microscopic examination of the treated groups showed multiple changes in the renal tubules and renal glomeruli including congestion, cellular infiltration, tubular degeneration, glomerular hypercellularity and glomerular tuft shrinkage. The expression of $\mathrm{Bcl} 2$ was increased in the treated groups and was focused in the glomerular endothelium and the epithelium of renal tubules; the expression in the tubules was more intense. The previous microscopic changes were also present in recovery group but at lesser degree.

Conclusion: The microscopic changes in the kidneys have been found to be similar to the picture of interstitial tubulonepherities, which was reversible changes.
\end{abstract}

\section{Introduction}

Acyclovir was the first agent in a novel group of antiviral medications called nucleosides analogues (Moomaw et al, 2003). Acyclovir is poorly absorbable via both oral and cutaneous administration (Hoglund et al, 2001). It is widely distributed in the body fluids including vesicular fluids, aqueous humar and cerebrospinal fluid (De Clercq 2004). Handerson et al. (1997) have stated that acyclovir cross placental barrier, secreted in the breast milk (Bork et al, 2000), and its main rout of excretion is the kidney (Moomaw et al., 2003). Within the virally infected cells, acyclovir is metabolized into acyclovir triphosphate that inhibits the synthesis of viral DNA by competing with 2-deoxyguanosie-triphosphate as a substrate for the viral DNA polymerase (Balfour, 1999). In vitro, acyclovir is greatly effective against Herpes simplex type 1, followed by Herpes simplex type 2 and Varicella Zoster virus. Whereas, the least effectiveness is against Epstein- Barr virus, Cytomegalo virus and Herpes type 6 (Balfour, 1999). Resistance to acyclovir is still uncommon, but could be more prevalent in immunocomprimised patients (Christophers et al., 1998). Acyclovir is available as tablets, oral suspensions, and injectable solutions ( Tod et al., 2001).

Many side effects have been reported after treatment with acyclovir, where neutropenia is the commonest finding (klimberlin et al., 2001). Amor and Amero (1983) have reported megaloplastic haemopioseis in patients treated with acyclovir against viral encephalitis. Moreover, neurosychiatric disorders have been reported in patients treated with acyclovir (Helldin et al., 2003). In rats, Bucur (1995) reported toxic effects on the liver, after administrations of the drug. Also, Sakiba et al., (1995) reported local retinal pigmented epithelium hypertrophy in the retina of rabbits injected with 
acyclovir.

Two models of cell death were recorded, the first was necrosis, and the second was apoptosis. A large family of genes that regulate apoptosis has been identified. The first anti-apoptotic gene identified is Bcl-2, which is a member of a large family of homodimerizing and heterodimerizing proteins, some of them inhibit apoptosis such as (Bcl-2 itself and $\mathrm{Bcl}-\mathrm{xl}$ ), while others (Bax, Bad, and Bcl-xl) favor programmed cell death (McDonnell 1996). Bcl2 protein is localized in the membrane of endoplasmic reticulum, nuclear envelop, and mitochondria. Over expression of $\mathrm{Bcl} 2$ suppresses apoptosis by preventing the activation of caspases that carry out the process (Wei et al., 2005)

\section{Material And Methods}

Forty adult male albino rats, weighing $300-350 \mathrm{~g}$, were subjected to the present study. Animals were divided into 4 groups; ten rats each. Animals were housed with free access to food and water, and maintained on a 12 hour light/dark cycle

The first group was served as control group. In the second group rats were intubated with the drug for one week. Each rat received $432 \mathrm{mg} / \mathrm{Kg} \quad$ B.Wt acyclovir suspended in distilled water by gavage once daily (Maximum therapeutic daily dose in rats) according to Tartaglione et al. (1991) using Paget table. In the third group rats were intubated with the drug for two weak. The fourth group served as recovery group, where animals were examined two weeks after cessation of the drug.

Acyclovir was obtained in the form of Zovirax suspension. Each $5 \mathrm{ml}$ contains 800 $\mathrm{mg}$ acyclovir. Zovirax suspension is manufactured for Smithkline Beecham, for Glaxo Wellcome, Egypt. Rats were sacrificed by rapid decapitation, and samples from the kidney were taken, fixed, and processed into paraffin sections of $5 \mu$ thickness.

Haematoxylin and Eosin Staining $(\mathrm{H}$ \&E) was done to demonstrate the morphological changes in the kidney and Paraffin serial sections of the kidney tissue were processed for immunohistochemical staining (Sternberger et al, 1970). Sections were incubated with ready to use primary antibody against $\mathrm{Bcl} 2$ at room temperature for 1 hour (Bio-Genex laboratories, San Ramon, CA, U.S.A). After washing, the sections were immunostained by Dako En Vision system. Diaminobenzidine (D.A.B.) was used as a chromagen. The first anti serum by phosphate buffered saline. The sections were counterstained with Haematoxylin.

Results were interpreted on the basis of quantitative analysis using OPTIMAS 6.5 software for image analysis and laboratory automation.

\section{Results}

Histological examination of the treated animals showed progressive morphological changes in the renal tubules, renal glomeruli and interstitial tissues. These changes were in the form of, congestion and cellular infiltration, which were more prominent in group 3 (fig.4\&6). The glomeruli showed hypercellularity and capillary tuft shrinkage as prominent pathological changes (Fig.5). The tubules showed tubular degeneration in the form of cloudy swelling (Fig. 4\&6), tubular dilatation and tubular casts as pathological changes (Fig. 4\&8). The interstitial tissue showed inflammatory reactions in the form of congestion, and inflammatory cell infiltration (Fig. 6\&8). In group 4; the recovery group; congestion, cloudy swelling of renal tubules and glomerular hypercellularity were present but less than that of the treated groups (Fig. 8). In control group minimal $\mathrm{Bcl} 2$ expression was found in the epithelium of the glomeruli and tubules (Fig. 9). The expression of $\mathrm{Bcl} 2$ was increased in the treated groups in both the glomerular endothelium and the epithelium of renal tubules (Fig.10\&11), whereas the expression in the tubules was more intense (Fig. 10). The expression of $\mathrm{Bcl} 2$ was more intense in the group 3 than in group 2 (Fig.11\&12). In recovery group Bc12 expression still present in both the glomerular endothelium and the epithelium of renal tubules but less than that of the treated group (Fig. 13). The relation between the $\mathrm{Bcl} 2$ exepression in the three groups were exepresed in (Fig 1) 
Table 1: the mean optical density values of different groups of rats examined for acyclovir.

\begin{tabular}{|l|c|c|c|c|}
\hline GROUPS & Control & 1 Week & 2Weeks & Recovery \\
\hline Mean O.D & 0.231678 & 0.293617 & 0.306622 & 0.264031 \\
\hline
\end{tabular}

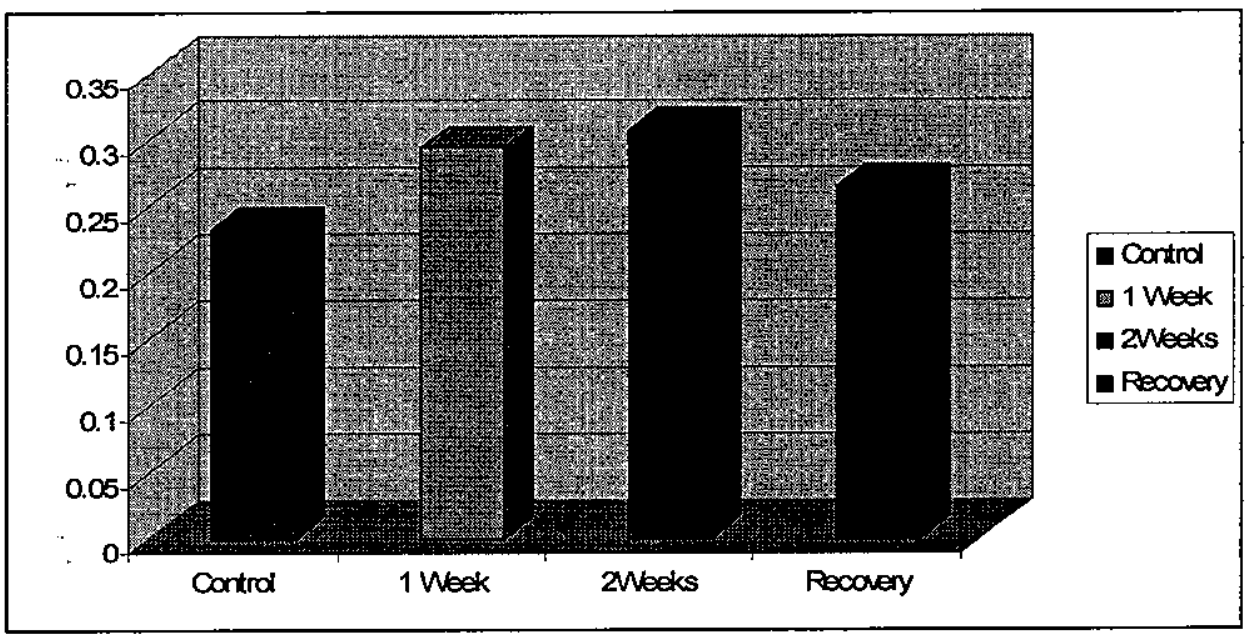

Fig. (1): histogram representing the relation between the mean optical density values of different groups of rats examined for acyclovir.

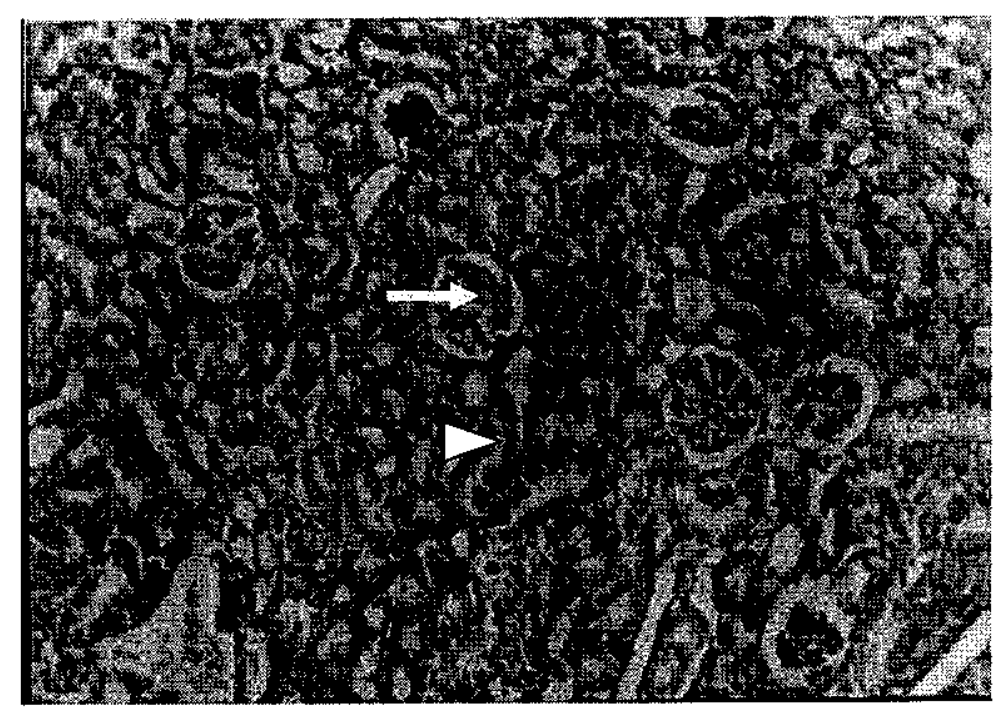

Fig. (2): A photomicrograph of a section in a control rat's kidney showing normal glomerular tuft (arrow) and tubules (arrow head).

(Hx \& E X100) 


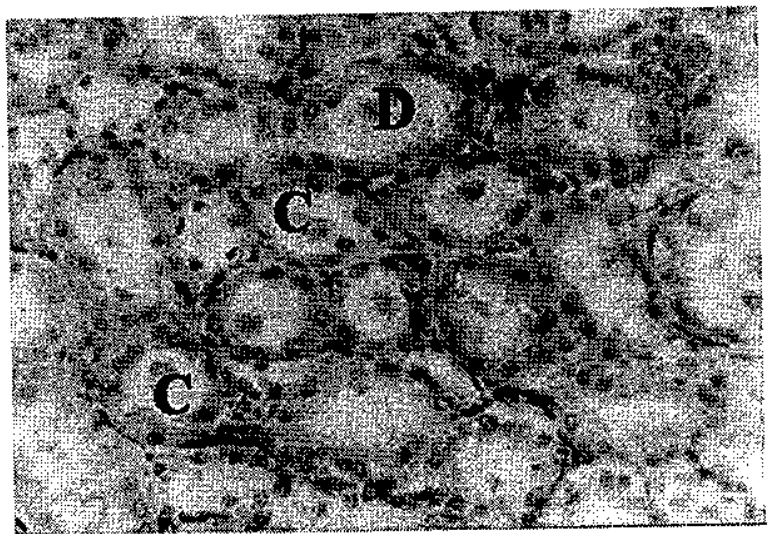

Fig. (3): A photomicrograph of a section from the kidney of a rat orally gavaged with the maximum therapeutic dose of acyclovir daily for 1 week showing tubular dilatation ( D ) with hyaline casts (C) and congestion of blood vessels. (H \& E X200)

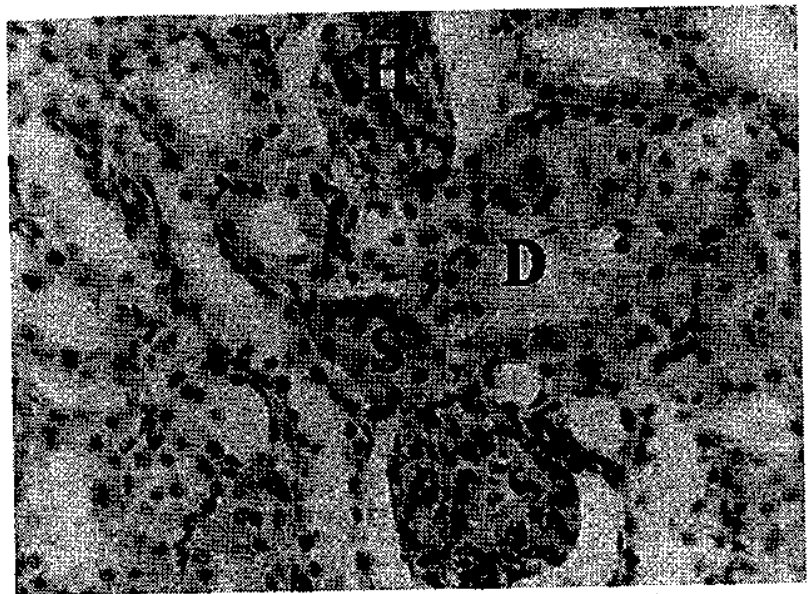

Fig. (4): A photomicrograph of a section from the kidney of a rat orally gavaged with the maximum therapeutic dose of acyclovir daily for 1 week showing glomerular hypercellularity ( $\mathrm{H}$ ) and cloudy swelling of the tubular epithelium (S ) with tubular dilation(D).

[ H\&E X200]

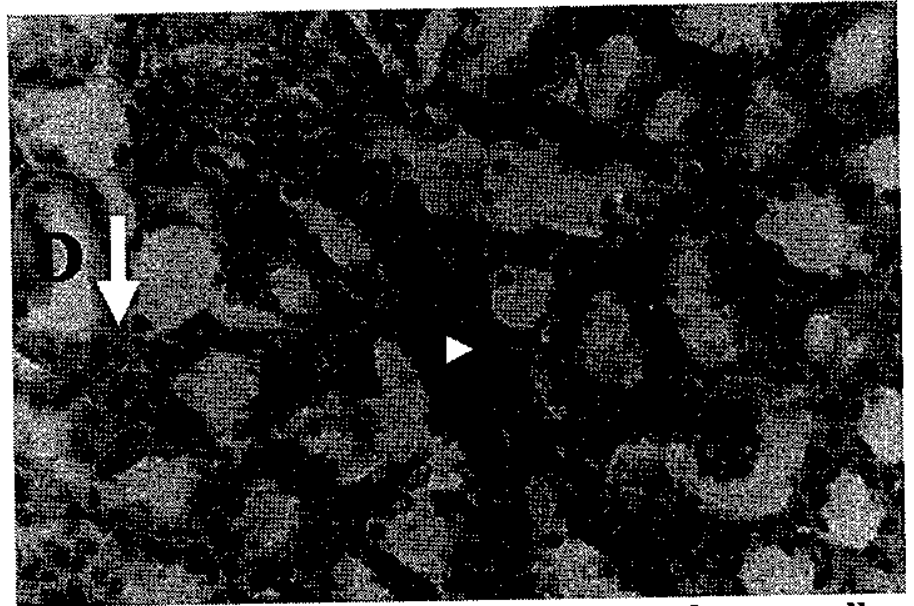

Fig. (5): A photomicrograph of a section from the kidney of a rat orally gavaged with the maximum therapeutic dose of acyclovir daily for 2 weeks showing marked tubular dilatation (arrow) with monocellular inflammatory cell infiltrates (arrow head).

(H \& E X200) 


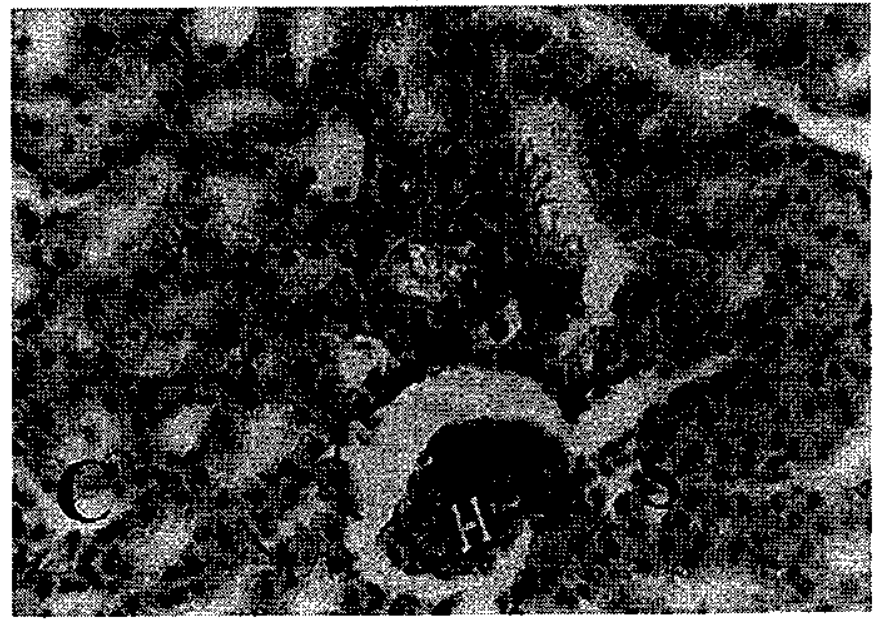

Fig. (6): A photomicrograph of a section from the kidney of a rat orally gavaged with the maximum therapeutic dose of acyclovir daily for 2 weeks showing glomerular hypercellularity and shrinkage of glomerular tuft ( $\mathrm{H}$ ), cloudy swelling of the tubular epithelium ( $S$ ).

(H \& E X200)

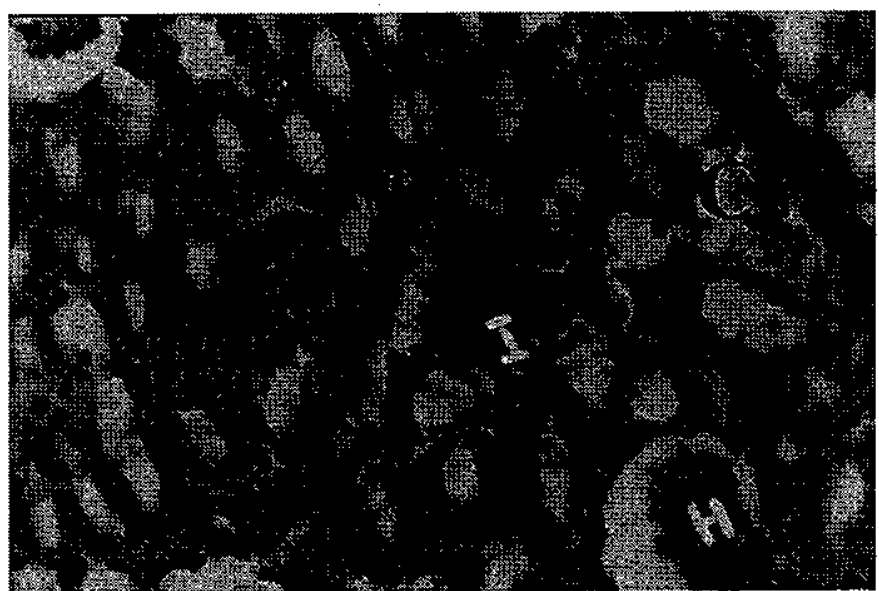

Fig. (7): A photomicrograph of a section from the kidney of a rat orally gavaged with the maximum therapeutic dose of acyclovir daily for 2 weeks showing glomerular hypercellularity ( $\mathrm{H}$ ) with monocellular inflammatory cell infiltrates (I) and a congested blood vessel $(C)$.

(H \& E X200)

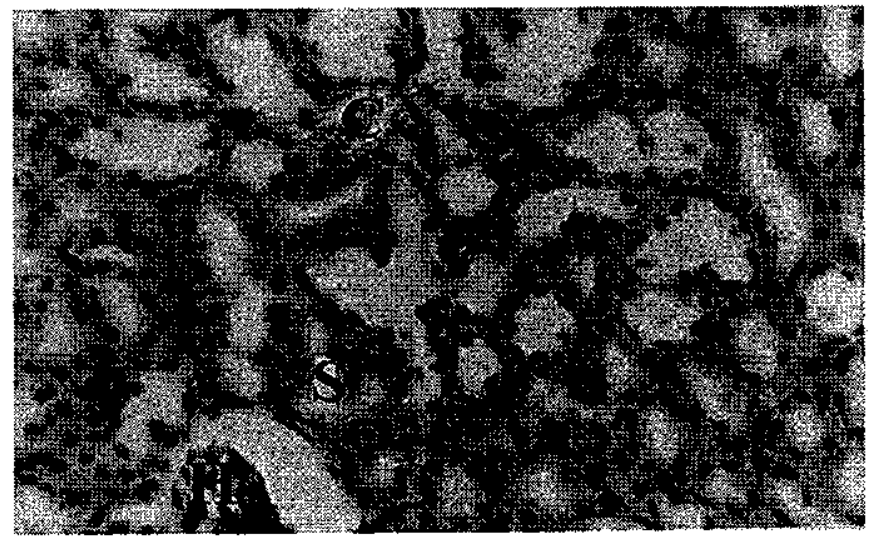

Fig. (8): A photomicrograph of a section from the kidney of a recovery group, 2 weeks of follow up, showing glomerular hypercellularity (H ) cloudy swelling of the tubular epithelium ( $S$ ) and a congested blood vessel( $C$ ).

(H \& E X200) 
The Effect Of Acyclovir On The Kidney Of Albino

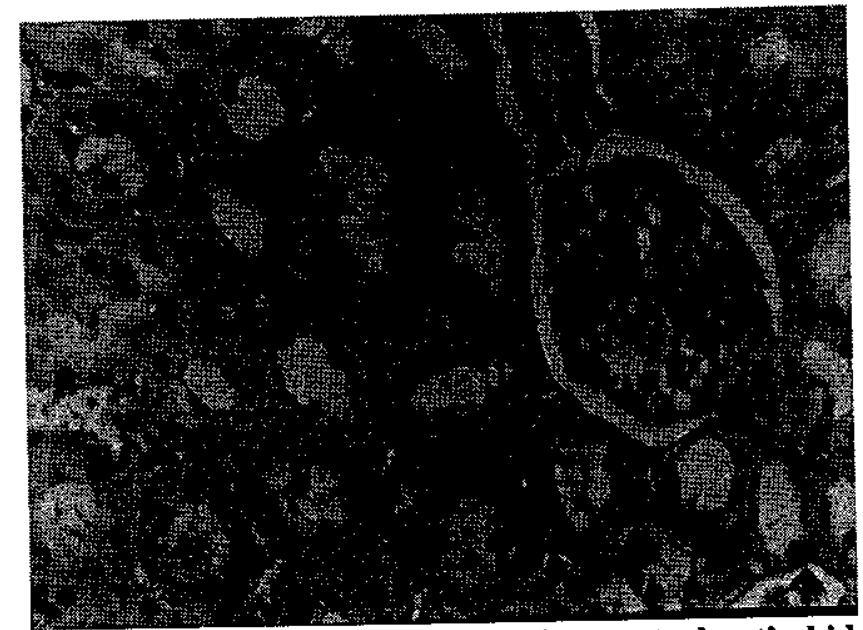

Fig. (9) A photomicrograph of a section in a positive control rat's kidney showing weak expression of bcl-2 in renal tubular epitheliumand glomerular epithelium (arrows)

(Immunostaining with anti-Bcl-2\& Mayer's Hx counter stain X 400)

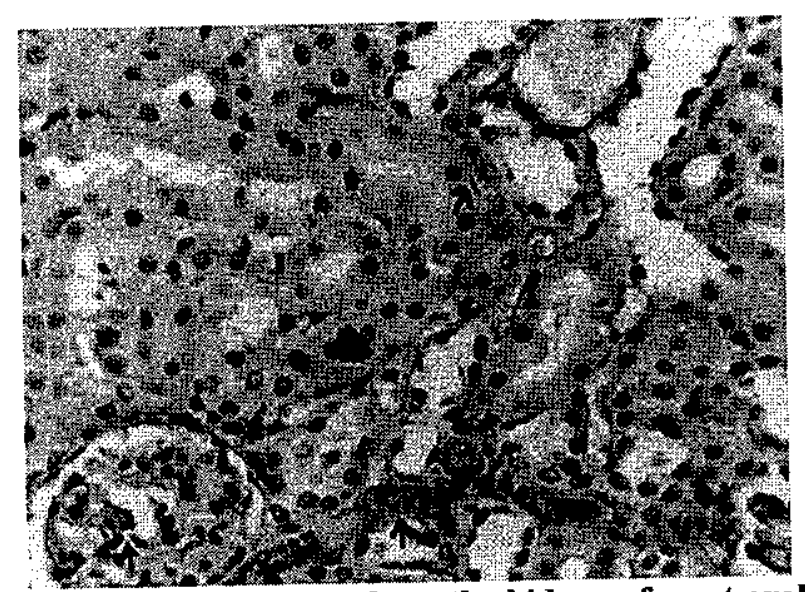

Fig. (10) A photomicrograph of a section from the kidney of a rat orally gavaged with the maximum therapeutic dose of acyclovir daily for 1 weeks showing moderate expression in renal tubular epithelium (arrows).

(anti-Bcl-2\& Mayer's Hx counter stain $x$ 400)

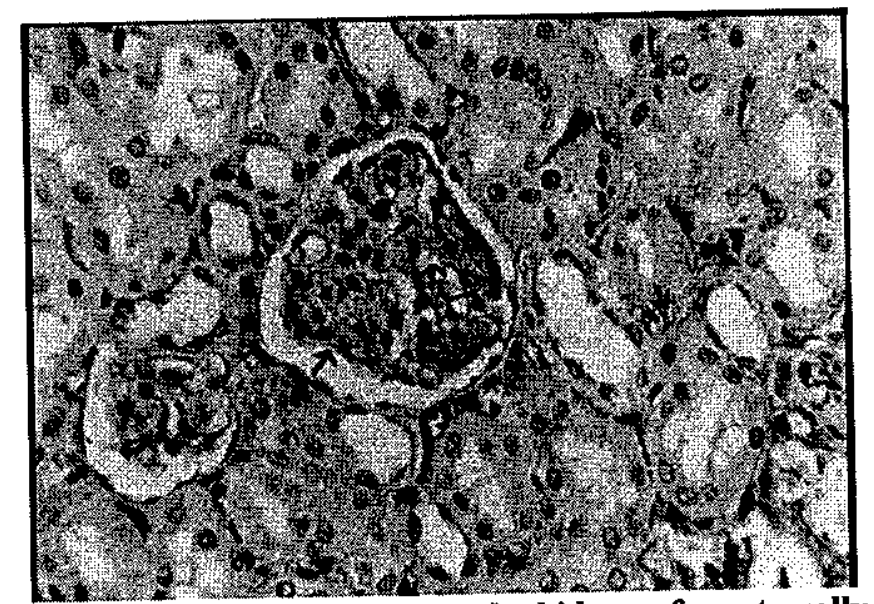

Fig. (11) A photomicrograph of a section from the kidney of a rat orally gavaged with the maximum therapeutic dose of acyclovir daily for 1 weeks showing moderate expression of bcl-2 in glomerular epithelium, (arrows). (anti-Bcl-2 \& Mayer's Hx counter stain X 400) 


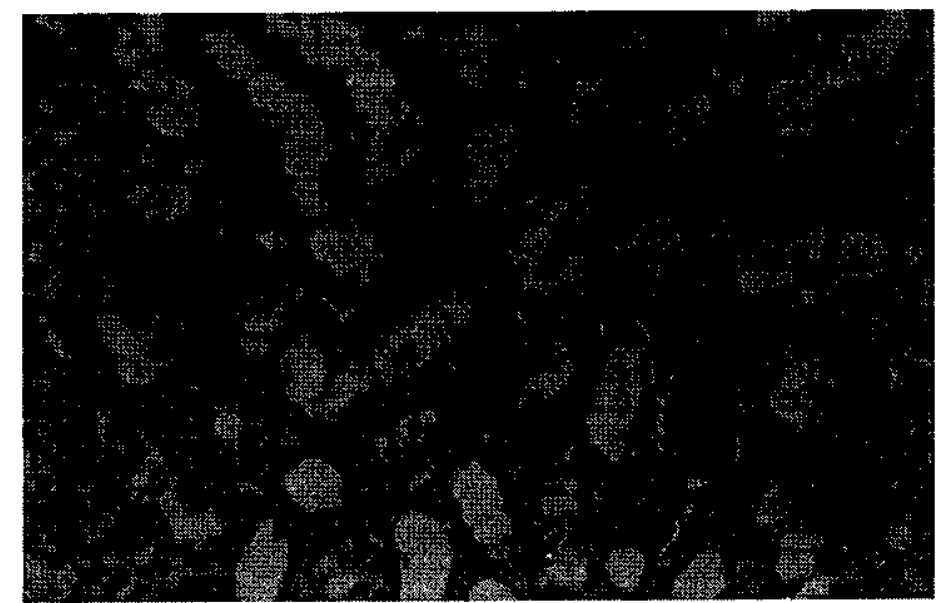

Fig. (12) A photomicrograph of a section from the kidney of a rat orally gavaged with the maximum therapeutic dose of acyclovir daily for 2 weeks showing marked expression of bcl-2 in renal tubular epithelium (arrows). (anti-Bcl-2\& Mayer's Hx counter stain $x$ 400)

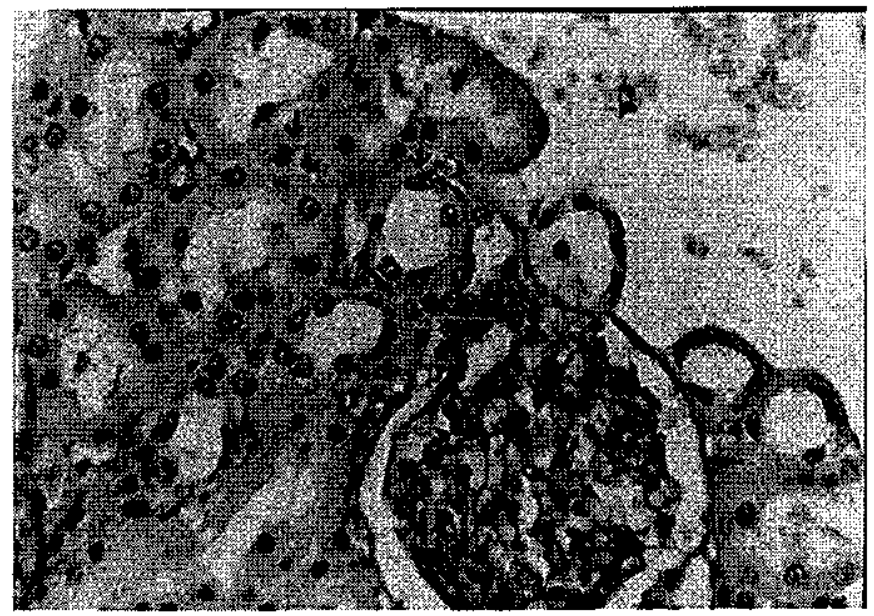

Fig. (13) A photomicrograph of a section from the kidney of recovery group showing mild expression of $\mathrm{Bcl} 2$ in glomerular endothelium and mild expression in renal tubules (arrows). (anti-Bcl2 \& Mayer's Hx counter stain X 400)

\section{Discussion}

Acyclovir has a clearance of about $250 \mathrm{ml} / \mathrm{min} / 1.73 \mathrm{~m}^{2}$; three times that of the glomerular filtration rate, indicating that both glomerular filtration and active tubular secretion contribute in its excretion (Moomaw et al. 2003). About $62 \%$ to $91 \%$ of acyclovir is excreted in unchanged form (Parfitt, 1999). Microscopic examination of kidney sections in treated rats for one week revealed pathological changes in both renal glomeruli and renal tubules. The glomerular changes were in the form of focal glomerular hypercellularity and capillary tuft shrinkage while those in the tubules were in the form of tubular degeneration, tubular dilatation, tubular casts, inflammatory cell infiltrates and congestion. On the other hand, administration of the drug for another week has resulted in progressive increase in the morphological changes. In the recovery groups these changes were present in less degree. The picture of these changes was similar to either tubulointerstitial nephritis or focal glomerulonephrtitis.

Eknoyan (1997) has defined tubulointerstitial nephritis as a pathological condition where the morphological changes 
involve predominately the tubules and interstitium. Glomerular abnormalities may also be present but either mild or occur only in the advanced stages of the disease. Also, Heptinstall (1992) has defined focal glomerulonephrtitis as a condition in which certain number of glomeruli were affected but others" remaining normal. The deference between the two conditions is of great importance due to the fact that renal failure resulted from tubulo-interstitial nephritis is reversible while the other is irreversible. Additionally, Jordan (1992) has stated that acute renal failure due to renal tubular injury is usually reversible provided that the cause (e.g. ischemia or nephrotoxins) is withdrawn. However glomerulonephritis and vasculitis may need immunotherapy for complete recovery of the renal functions.

In the present study the morphological changes induced by acyclovir were indicative of tubulo-interstitial nephritis and the glomerular changes were secondary to tubulo-interstitial nephritis. These pathological changes were predominant in the tubules. This result was more obvious in immunostaining, where $\mathrm{Bcl} 2$ reaction was more predominant in the renal tubules of treated animals. On the other hand, the reaction in the glomerular epithelium was much weaker than that of the tubules. This result was also obtained by Sawyer and coworkers (1988) who examined the kidney biopsies of 2 cases developed acute renal failure after oral administration of acyclovir at a dose of $800 \mathrm{mg} /$ day for one month. They have found focal lesions of interstitial hemorrhage, congestion, and inflammatory infiltrates comprised of lymphocytes, plasma cells and eosinophils. Occasional tubules were ruptured but none exhibited necrosis. The glomeruli and vessels were normal. Becker et al (1993) studied 3 cases with acyclovir induced renal failure by electron microscopy, which revealed flattening of the lining cells of the proximal and distal tubules with focal nuclear loss. The result of the present study were consistent with Rashed et al., (1990) who have reported two cases developed acyclovir-induced tubulo- interstitial nephritis that terminated with acute renal failure following acyclovir infusion. Renal biopsies that have been done during the acute phase of renal failure demonstrated interstitial edema, esinophils and cellular aggregates. The histopathological changes recorded in the present study could be explained by the fact that the kidney accounts for $75-80 \%$ of the total clearance of acyclovir. This elimination occurs mainly by active tubular secretion (AlMatter et al, 2004; Filer et al, 1994). Acyclovir crystallization in the renal tubules with subsequent obstructive nephropathy has been suggested by many studies as a generally presumed mechanism of acyclovir induced nephrotoxicity (Saywer et al., 1988). On the other hand, Becker et al (1993) attributed acyclovir induced nephrotoxicity to direct toxic effects of the drug on renal tubules with no evidence of crystalluria or crystal deposition.

Immunolocalization of $\mathrm{Bcl}-2$ in kidney specimens of control groups revealed that Bcl-2 was weakly expressed in both the tubules and the glomeruli. This result was parallel to Ortiz et al., (1993) and Vecchione et al., (2004) who have stated that Bcl-2 is expressed by normal renal cells including mesangial cells, tubular epithelium, fibroblasts and metanephric stem cells. Over expressing of $\mathrm{Bcl}-2$ is either refractory to apoptosis or have a cell cycle delay (Janumyan et al, 2003). Acyclovir treatment has induced changes in the pattern of immunolocalization of $\mathrm{Bcl}-2$ that found in kidney of control group. It was concluded that $\mathrm{Bcl}-2$ has two genetically separated functions; the first is anti apoptotic and the second is cell cycle regulator (Janumyan et al., 2003). Experimental studies have established a role for $\mathrm{Bcl}-2$ in slowing the progression of cell cycle (Vairo et al.; 2000 and Ortiz 2000). Bcl2 could control the cell cycle events by delaying cell cycle entry into $\mathrm{S}$ phase. Cells over expressing $\mathrm{Bcl} 2$ were found to be arrested at all phases of cell cycle (Basu and Haldar, 1998).

Acyclovir treatment has resulted in progressive over-expression of $\mathrm{Bcl}-2$ in the tubular epithelium. The Bcl-2 expression of recovery group was less than that of treated group but higher than that of control group. The pattern of tubular-interstitial damage with over-expressed $\mathrm{Bcl} 2$ by the renal tubules was observed in treated animals and also reported by Chevalier et al., (2000) 
who observed $\mathrm{Bcl} 2$ over expression in renal tubules in case of experimental chronic obstructive nephropathy. This overexpression was explained by Zhang et al., (2001) as a compensatory tubular epithelial proliferation. Moreover, Rodriguez-Lopez et al., (20202) observed that Bcl-2 was over expressed during the genesis of early tubule-interstitial damage in the experimental model of uninephrectomized hypertensive rats.

The results of the present work were in agreement with Ortiz et al., (1996) who stated that over expression of $\mathrm{Bcl}-2$ was associated with many renal diseases. In contrast to the present results was OrtizArduan and Neilson (1994) who have observed that acute toxic renal failure was accompanied by bcl2 down-regulation in mice. Down-regulation of this protective protein had resulted in renal damage. Ortiz et al., (1996) stated that Bcl-2 does not protect against all forms of cell death which could be explained by the need that this protein has to work in union with other associated proteins to exert its anti apoptotic effect.

In conclusion the antiviral drug, acyclovere, has nephrotoxic effect, which is mainly interstitial tubulonepherities. Which in turn could cause secondary glomerulonepherities, these kidney changes were reversible.

\section{References}

1. Al-Matter $\mathbf{E}$ R, Bourahma $\mathbf{M} \mathbf{H}$ and Aboobacker K C (2004): Acyclovir Induced Reversible Renal Failure in an Immunocompromised Child with Extensive Cutaneous Herpes Zoster. Kuwait Medical Journal, 36 (1): 47-48

2. Basu $A$ and Haldar $S$ (1998): The relationship between Bcl2, p53 and Bax: consequence for cell cycle progression and cell death. Molecular Human Reproduction., 4(12): 1099-1109.

3. Becker BN, Fall P, Hall C, Milam D, Leonard J, Glick $A$ and Schulman $G$ (1993): Rapidly progressive acute renal failure due to acyclovir: case report and review of literature. Am. J. Kidney Dis., 22(4): 611-5.

4. Chevalier RL, Smith CD, Wolstenholme J, Krajewski $S$ and Reed J C (2000): Chronic ureteral obstruction in the rat suppresses renal tubular $\mathrm{Bcl}-2$ and stimulates apoptosis. Exp. Nephrol. , 8 (2) : 115-22.

5. Eknoyan G (1997): Acute tubulointerstitial nephritis. In: Diseases of the Kidney. Schreier, R.W. and Gottschalk, C.W. (eds.). (sixth ed). Little, Brown and Company; vol II: 1249-72.

6. Filer CW, Allen GD, Brown TA, Fowles SE, Hollis FJ, Mort EE, Prince WT and Ramji JV (1994): Metabolic and pharmacokinetic studies following oral administration of $14 \mathrm{C}$-famciclovir to healthy subjects. Xenobiotica., 24 (4) :357-68.

7. Helldén A, Odar-Cederlöf I, Diener P, Barkholt L, Medin C, Svensson J-O, Säwe $J$ and Ståhle L (2003): High serum concentrations of the acyclovir main metabolite 9-carboxymethoxymethylguanine in renal failure patients with acyclovir-related neuropsychiatric side effects: an observational study. Nephrol Dial Transplant, 18: 1135-1141.

8. Heptinstall RH (1992) : Classification of glomerulonephritis; focal, and mesangial proliferative forms of glomerulonephritis; recurrent hematuria. In:Pathology of the kidney, $4^{\text {th }}$ edition, Little, Brown and Company, Boston, Toronto, London, chp.4, (1) pp 261-274.

9. Janumyan $Y \quad M$, Sansam $C G$, Chattopadhyay A, Cheng N, Soucie E L, Penn L Z, Andrews D, Knudson CM and Yang E (2003): Bcl-xL/Bcl-2 coordinately regulates apoptosis, cell cycle arrest and cell cycle entry. EMBO J., 22: 5459-5470.

10. Jordan C (1992): Vascular Disorders of the Kidney chapter in Cecil Textbook of Medicine. Edited by Wyngaarden, Smith and Bennett, 19th Edition, Saunders, pp 598-599

11. McDonnellTJ( 1996):Importance of the $\mathrm{Bcl} 2$ family in cell death regulation. Experientia,952--1008

12. Ortiz A, Karp SL, Danoff TM and Neilson EG (1993): Expression of survival promoting bci 2 oncogene by renal cells and whole kidney. $J$ Am Soc Nephrol., 4,742 (abst.).

13. Ortiz A Cuadrado $\mathbf{S}$ G, Lorz $C$ and Egido J (1996): Apoptosis in renal diseases. Frontiers in Bioscience., 1(1): 30-47.

14. Ortiz A (2000): Nephrology forum: Apoptotic regulatory proteins in renal injury. Kidney Int. 58: 467-485.

15. Ortiz-Arduan, A. and Neilson EG (1994): Apoptotic cell death in renal disease. Nefrología, 14:391-407 (abst.).

16. Rashed A Azadeh B and Abu Romeh S.H. (1990): acyclovir-induced acute 
tubulo-interstitial nephritis. Nephron; 56(4):"436-8.

17. Rodriguez-Lopez AM, Flores $O$, Werevalo MA and Lopez-Novoa JM (2002): Tubular cell apoptosis and proliferation in the early phase of renal damage in uninephrectomized SHR. Kidney Blood Press Res., 25(1):13-9.

18. Sawyer MH, Weeb DE, Balow $J E$ and Straus S E (1988): Acyclovir induced renal failure: clinical course and history. The American Journal of Medicine, 48: 1067-1071

19. Sternberger et al ,,(1970): Immunohistochemistry $2^{\text {nd }}$ ed.,PP. 104-169,wiley medical Pup.New York

20. Tartaglione TA, Collier AC, Ophein K and Corey L (1991): Pharmacokinetics evaluation of low and high dose acyclovir in patient with symptomatic human immune deficiency viral infection. Antimicrob. Agent Chemther., 35(11): 2225-2231.
21. Vairo G Soos TJ, Upton 'TM, Zalvide $J$, DeCaprio JA, Ewen ME, Koff $A$ and Adams JM (2000): Bcl-2 retards cell cycle entry through p27 (Kip1), pRB relative p130, and altered E2F regulation. Mol Cell Biol., 20: 4745-4753

22. Vecchione A, Galetti T P, Gardiman M, Ishii H, Giarnieri E, Pagano F, Gomella $L G$, Croce $C M$ and Baffa $R$ (2004): Collecting duct carcinoma of the kidney: an immunohistochemical study of 11 cases. BMC Urolog, 4:11-14

23. Wei $P$, Jin $X$, Zhang $X-S$, Hu ZY, Han CS and Liu, YX (2005): Expression of $\mathrm{Bcl}-2$ and $\mathrm{p} 53$ at the fetal-maternal interface of rhesus monkey. Reproductive Biology and Endocrinology, 3(1):4

24. Zhang G, Oldroyd SD, Huang LH, Yang B, Li Y, Ye R and El Nahas AM (2001): Role of apoptosis and $\mathrm{Bcl}-2 / \mathrm{Bax}$ in the development of tubuloin-terstitial fibrosis during experimental obstructive nephropathy. Exp. Nephrol. , 9(2):71-80 


\section{البيضاء الجرذان كلي السيكلوفير على تأثير عقار \\ وكيميائية مناعية هستولوجية دراسة}

\section{أمير محمد بسام - السيد جلال خضر - صلاح الدسوقى مراد - جمال أبوالحسن بقسمى الهستولوجى والتشريح بكلية الطب جامعة الازهر}

يستخدم عقار السيكلوفير فى علاج كثير من الامراض الفيروسية مثل التهاب الكبد الوبائى والقوباء الجلدى ومرض نقص المناعة الذاتية كما يستخدم فى علاج بعض انوأع السرطانات .وقد سجلت كثير من الاثار الجانبية لهذا العقار على الكبد وشبكية العين والجهاز العصبى والكلى , ولتقييم اثر هذا الدواء على الكليتين صممت هذه الدراسة حيث استخدم اربعون من ذكور الجرذان البيضاء قسمت الى اربع مجموعات الاولى كمجموعة ضابطة والثانية اعطيت العقار لمدة اسبوع والثالثة أعطيت العقار لمدة اسبوعين اما المجموعة الرابعة فقد اوقف عنها العقار لمدة اسبوعين لدراسة مدى تاثير توقف العقار على الاثار الجانبية .وقد تم ذبح الحيوانات المستخدمة في نهاية كل فترة مصممة فى البحث وتم اخذ عينات من الكليتين حيث تم فحصها بصبغة الهيماتوكسيلين والايوسين وكذلك بصبغة كيمياء الانسجة المناعية الخاصة وقد اثبتت الدراسة ان للعقارتاثير سام على الكلى وظهر ذلك فى صورة انكماش في كبيبات الكلى وفرط فى انتسام الخلايا وايضا احتقان النسبج الخلالى الكلوى وتنكرز انيببات الكلى فى حين ظهر تحسن واضح فى نسيج الكلى مع توقف اعطاء العقار لفترة اسبوعين. 